\title{
Mosquito Larvicidal Activity on Aedes albopictus and Constituents of Essential Oils from Manglietia dandyi (Gagnep.) Dandy
}

\section{Pham H. Ban 1, Le D. Linh 1, Le T. Huong 1, Tran M. Hoi 2, Nguyen H. Hung ${ }^{3}$, Do N. Dai ${ }^{4,5}$," and Isiaka A. Ogunwande ${ }^{6, *}$}

\author{
${ }^{1}$ School of Natural Science Education, Vinh University, 182 Le Duan, Vinh City, Nghệ An Province, \\ Vietnam \\ ${ }^{2}$ Institute of Ecology and Biological Resources, Vietnam Academy of Science and Technology, 18- \\ Hoàng QuốcViệt, Cầu Giấy, Hà Nọi, Vietnam \\ ${ }^{3}$ Center for Advanced Chemistry, Institute of Research and Development, Duy Tan University, 03 \\ Quang Trung,Da Nang, Vietnam \\ ${ }^{4}$ Graduate University of Science and Technology, Vietnam Academy of Science and Technology, \\ 18Hoang QuocViet, Cau Giay, Hanoi, Vietnam \\ ${ }^{5}$ Faculty of Agriculture, Forestry and Fishery, Nghe An College of Economics, 51-Ly Tu Trong, Vinh City, \\ Nghe AnProvince, Vietnam \\ ${ }^{6}$ University Drive, Aleku Area, Osogbo, Nigeria
}

(Received July 18, 2019; Revised September 08, 2019; Accepted September 19, 2019)

\begin{abstract}
Herein, we report the results of our investigation on essential oils obtained by hydrodistilation of the leaves and fruits of Manglietia dandyi (Gagnep.) Dandy. The constituents of the oils were analyzed by gas chromatography-flame ionization detector (GC-FID) and gas chromatography-mass spectrometry (GC-MS). The yields of the oils were $0.25 \%$ and $0.21 \%$ (v/w, leaf and fruit respectively), calculated on a dry weight basis. The main constituents of the leaf oils were $(E)$-nerolidol $(18.4 \%)$ and $\alpha$-selinene $(11.0 \%)$ while the fruit oils contained abundance of $\beta$-caryophylene $(27.7 \%), \delta$-cadinene $(13.7 \%), \alpha$-humulene $(13.2 \%)$ and $\alpha$-copaene (11.6\%). The results indicated that $M$. dandyi leaf oil exhibited $96 \%$ and $100 \%$ mortality towards the fourthinstant larvae of Aedes albopictus at $24 \mathrm{~h}$ at tested concentrations of $50 \mu \mathrm{g} / \mathrm{mL}$ and $100 \mu \mathrm{g} / \mathrm{mL}$. The oil only displayed $100 \%$ mortality at concentrations of 50 and $100 \mu \mathrm{g} / \mathrm{mL}$ and under $48 \mathrm{~h}$. The minimum lethal concentrations, $\mathrm{LC}_{50}$, were $29.57 \mu \mathrm{g} / \mathrm{mL}(24 \mathrm{~h})$ and $29.02 \mu \mathrm{g} / \mathrm{mL}\left(48 \mathrm{~h}\right.$ ); while the $\mathrm{LC}_{90}$ values of $46.21 \mu \mathrm{g} / \mathrm{mL}$ and $42.29 \mu \mathrm{g} / \mathrm{mL}$ were obtained respectively at $24 \mathrm{~h}$ and $48 \mathrm{~h} \mu \mathrm{g} / \mathrm{mL}$. The chemical constituents and larvicidal action of M. dandyi essential oils are being reported for the first time.
\end{abstract}

Keywords: Manglietia dandyi; essential oil; sesquiterpenes; larvicidal activity. ㄷ 2020 ACG Publications. All rights reserved.

\section{Plant Source}

In the course of extensive studies on aromatic plants from Vietnam [1,2], we investigated Manglietia dandyi (Gagnep.) Dandy (Magnoliaceae). Herein, the chemical constituents of the essential oils from the leaf and

\footnotetext{
*Corresponding author: E-Mail: daidn23@gmail.com ; isiakaogunwande@ gmail.com
} 
fruit as well as the larvicidal activity of the leaf oil were reported. The leaves and fruits of $M$. dandyi were collected from Vũ Quang National Park, Hà Tĩnh (GPS: 18²0'N 105 54'E), Vietnam, in August 2018, and identified by Dr. Ngoc Dai. A voucher specimen (LDL 719) was deposited at the Botany Museum, Nghệ An College of Economics, Vietnam.

\section{Previous Studies}

Till moment no previous investigation has been carried out on the volatile composition and biological activity of both volatile and non-volatile components of $M$. dandyi. However, sesquiterpene compounds were reported to constitute the main constituents of other Maglienta oils analysed previously from Vietnam [3] and China [4].

\section{Present Study}

Hydrodistillation of the air dry parts of $M$. dandyi produced strong, odorous clear yellow oils. The volatile oils were obtained in yields of $0.25 \pm 0.01 \%$ (v/w, leaf) and $0.21 \pm 0.01 \%$ (v/w, fruit). Table 1 summarizes the identified components in order of their elution on the HP-5MS column used for the GC-MS analysis. Forty-seven compounds representing $93.8 \%$ of the oil contents were identified in the leaf of $M$. dandyi. These comprised of sesquiterpene hydrocarbons (49.9\%), oxygenated sesquiterpenes (30.9\%), monoterpene hydrocarbons and oxygenated monoterpenes $(2.4 \%)$. The main constituents of the leaf oil were $(E)$-nerolidol $(18.4 \%)$ and $\alpha$-selinene $(11.0 \%)$. In addition, significant quantity of $\delta$-cadinene $(7.5 \%), \alpha$-copaene $(6.0 \%)$ and $\beta$-selinene (6.0\%) were also present in the oil. On the other hand, 53 compounds accounting for $99.2 \%$ of the oil contents were identified in the fruit of $M$. dandyi. Sesquiterpene hydrocarbons (82.0\%) along with oxygenated sesquiterpenes $(8.4 \%)$, monoterpene hydrocarbons $(4.8 \%)$ and oxygenated monoterpenes (4.0\%) represent the classes of compounds identified in the fruit oil. $\beta$-Caryophylene $(27.7 \%), \delta$-cadinene (13.7\%), $\alpha$-humulene (13.2\%) and $\alpha$-copaene (11.6\%) were the compounds occurring in higher amounts in the fruit oil.

Table 1. Chemical composition of essential oils of Manglietia dandyi

\begin{tabular}{lcccc}
\hline Compound & RI & RI & Leaf $^{\mathbf{c}}$ & Fruit $^{\mathbf{c}}$ \\
\hline$\alpha$-Pinene & 937 & 937 & 0.7 & 0.7 \\
Camphene & 954 & 946 & 0.6 & 1.1 \\
$\beta$-Pinene & 983 & 980 & 1.0 & 0.2 \\
Myrcene & 990 & 988 & 0.5 & 0.2 \\
$\alpha$-Phellandrene & 1009 & 1004 & 0.6 & 0.5 \\
$\alpha$-Terpinene & 1020 & 1014 & 0.3 & 0.1 \\
$o$-Cymene & 1028 & 1026 & 2.4 & 0.5 \\
Limonene & 1032 & 1030 & 3.7 & 0.8 \\
$\beta$-Phellandrene & 1034 & 1032 & 0.8 & 0.4 \\
$\gamma$-Terpinene & 1062 & 1056 & - & 0.2 \\
Terpinolene & 1092 & 1093 & - & 0.1 \\
Linalool & 1102 & 1100 & 2.3 & 1.7 \\
Borneol & 1176 & 1168 & - & 0.3 \\
$\alpha$-Terpineol & 1198 & 1197 & 0.1 & - \\
Geraniol & 1256 & 1254 & - & 0.3 \\
Bornyl acetate & 1292 & 1297 & - & 0.7 \\
$\alpha$-Cubebene & 1358 & 1356 & - & 0.2 \\
Cyclosativene & 1380 & 1371 & - & 0.1 \\
Isoledene & 1380 & 1373 & - & 0.1 \\
Geranyl acetate & 1382 & 1380 & - & 1.0 \\
$\alpha$-Ylangene & 1383 & 1383 & - & 0.2 \\
$\alpha$-Copaene & 1388 & 1387 & 6.0 & 11.6 \\
$\alpha-$-Gurjunene & 1423 & 1420 & 1.0 & 0.5 \\
& & & & \\
\hline
\end{tabular}




\begin{tabular}{|c|c|c|c|c|}
\hline \multicolumn{5}{|l|}{ Table 1 continued.. } \\
\hline$\beta$-Caryophylene & 1437 & 1432 & 2.6 & 27.7 \\
\hline$\beta$-Gurjunene & 1443 & 1438 & 0.2 & 0.5 \\
\hline Aromadendrene & 1445 & 1440 & 2.2 & 1.2 \\
\hline (Z)- $\beta$-Farnesene & 1458 & 1447 & 0.7 & 0.1 \\
\hline$\alpha$-Humulene & 1471 & 1465 & 1.2 & 13.2 \\
\hline 9-epi-(E)-Caryophyllene & 1477 & 1470 & 0.5 & 0.5 \\
\hline trans-Cadina-1(6),4-diene & 1486 & 1484 & - & 1.4 \\
\hline$\beta$-Chamigrene & 1487 & 1487 & 1.8 & - \\
\hline$\gamma$-Muurolene & 1488 & 1488 & 1.8 & 1.3 \\
\hline$\alpha$-Amorphene & 1492 & 1490 & 0.5 & 0.2 \\
\hline$\beta$-Selinene & 1503 & 1502 & 6.0 & 1.1 \\
\hline$\gamma$-Amorphene & 1509 & 1510 & 0.2 & 3.7 \\
\hline$\alpha$-Selinene & 1511 & 1513 & 11.0 & - \\
\hline$\gamma$-Cadinene & 1528 & 1525 & 1.1 & 0.7 \\
\hline$\delta$-Cadinene & 1532 & 1530 & 7.5 & 13.7 \\
\hline cis-Calamenene & 1537 & 1534 & 2.4 & 1.0 \\
\hline Zonarene & 1539 & 1540 & 1.0 & 0.7 \\
\hline trans-Cadina-1,4-diene & 1546 & 1544 & - & 0.9 \\
\hline$\alpha$-Cadinene & 1552 & 1548 & 0.4 & 0.3 \\
\hline$\alpha$-Calacorene & 1558 & 1554 & 0.7 & 0.9 \\
\hline Elemicine & 1559 & 1556 & 0.7 & - \\
\hline (E)-Nerolidol & 1568 & 1560 & 18.4 & 1.3 \\
\hline$\beta$-Calacorene & 1578 & 1578 & - & 0.2 \\
\hline Caryophyllene alcohol & 1591 & 1588 & 0.3 & 0.2 \\
\hline Viriflorol & 1603 & 1600 & 3.6 & 1.9 \\
\hline Cubeban-11-ol & 1612 & 1606 & 0.8 & 0.3 \\
\hline Rosifoliol & 1621 & 1620 & 0.6 & - \\
\hline Copaborneol & 1625 & 1628 & - & 0.7 \\
\hline Humulene epoxide II & 1630 & 1632 & - & 0.2 \\
\hline$\alpha$-Corocalene & 1637 & 1637 & 0.2 & - \\
\hline 5-Guaiene-11-ol & 1641 & 1640 & 0.9 & 0.2 \\
\hline 1-epi-Cubenol & 1645 & 1644 & 0.8 & 0.8 \\
\hline Cubenol & 1651 & 1652 & 0.4 & - \\
\hline epi- $\alpha$-Cadinol & 1659 & 1660 & 0.6 & 1.1 \\
\hline$\alpha$-Muurolol & 1662 & 1664 & 1.0 & 0.4 \\
\hline$\alpha$-Cadinol & 1672 & 1666 & 0.8 & 0.9 \\
\hline neo-Intermedeol & 1676 & 1672 & 2.3 & 0.4 \\
\hline Cadalene & 1693 & 1690 & 0.2 & - \\
\hline \multirow[t]{2}{*}{$(E, E)$-Farnesol } & 1726 & 1722 & 0.4 & - \\
\hline & & Total & 93.8 & 99.2 \\
\hline Hydrocarbons & & & 10.6 & 4.8 \\
\hline Oxygenated monoterpenes & & & 2.4 & 4.0 \\
\hline Sesquiterpene hydrocarbons & & & 49.9 & 82.0 \\
\hline Oxygenatedsesquiterpenes & & & 8.4 & \\
\hline
\end{tabular}

${ }^{\mathrm{a}}$ Retention indices on HP-5MS column; ${ }^{\mathrm{b}}$ Literature retention indices [5]; ${ }^{\mathrm{c}}$ Standard deviation were insignificant and excluded from the Table to avoid congestion; (-) Not identified

The high content of sesquiterpene compounds in the studied M. dandyi oils was in agreement with findings [3, 4]. This class of compounds occurred in abundance quantity in Maglienta oils analysed previously from Vietnam [3] and other parts of the world [4]. For example, the leaf oil of $M$. fordiana contained $\delta$-cadinene $(18.0 \%),(E)$-nerolidol $(16.7 \%), \alpha$-copaene $(12.8 \%)$ and $\alpha$-selinene $(9.1 \%)$ while $\beta$-caryophyllene $(29.9 \%), \alpha$ humulene $(7.4 \%)$, (E)-nerolidol $(6.3 \%)$ were the main compounds in M. conifera [3]. High contents of $(E)$ - 
nerolidol (14.61\%) and $\delta$-cadinol $(20.57 \%)$ were identified in M. moto, while $(E)$-nerolidol $(11.92 \%)$ and $\delta$ cadinene (10.84\%) were present in M. yuyanensis growing in China [4].

The mosquito larvicidal activity of $M$. dandyi leaf oil depicted by percentage mortality and lethal concentrations are summarized in Table 2. The oil sample exhibited 96\% (concentration of $50 \mu \mathrm{g} / \mathrm{mL}$ ) and $100 \%$ (concentration of $100 \mu \mathrm{g} / \mathrm{mL}$ ) mortality against the larvae of Ae. albopictus at $24 \mathrm{~h}$. Likewise, M. dandyi displayed $100 \%$ mortality against the larvae of Ae. albopictus at $48 \mathrm{~h}$ (concentrations of 50 and $100 \mu \mathrm{g} / \mathrm{mL}$ ). There was no mortality in the EtOH used as control. The percentage mortality was dependent on the concentration of the tested oil samples. Thus, higher inhibition of mosquito larvae was observed in the $100 \mathrm{mg} / \mathrm{L}$ compared to other concentrations. From Table 2, the M. dandyi leaf oil exhibited larvicidal action towards Ae. albopictus with $\mathrm{LC}_{50}$ values of $29.57 \mu \mathrm{g} / \mathrm{mL}$ and $\mathrm{LC}_{90} 46.21 \mu \mathrm{g} / \mathrm{mL}$ at $24 \mathrm{~h}$ while $\mathrm{LC}_{50}$ values of $29.02 \mu \mathrm{g} / \mathrm{mL}$ and $\mathrm{LC}_{90}$ of $42.29 \mu \mathrm{g} / \mathrm{mL}$ were obtained at $48 \mathrm{~h}$. Permethrin, the standard drug used as control displayed larvicidal activity at much lower values. These findings showed that the concentrations of test substances affected degree of toxicity and mortality rates. The larvicidal activity of Maglienta oil samples has not been the subject of much literature discussion. Overall results in this study showed that essential oil of $M$. dandyi exhibited good mortality and larvicidal activity on Ae. Albopictus larvae when compared to M. garrettii [6]. Also, Magnolia grandiflora of the Magnoliaceae family displayed larvicidal activity against Ae. aegypti with $\mathrm{LD}_{50}$ values in the range between 51.5 and $54.7 \mathrm{ppm}$ [7].

Table 2. Larvicidal activity of Manglieta dandyi leaf essential oil against Aedes albopictus

\begin{tabular}{|c|c|c|}
\hline & \multicolumn{2}{|c|}{ Mortality (\%) } \\
\hline Concentration $(\mu \mathrm{g} / \mathrm{mL})$ & $24 h^{a}$ & $48 h^{a}$ \\
\hline 12.5 & $5 \pm 0.000$ & $10 \pm 0.000$ \\
\hline 25 & $15 \pm 1.633$ & $27.5 \pm 1.915$ \\
\hline 50 & $96 \pm 0.500$ & $100 \pm 0.000$ \\
\hline 100 & $100 \pm 0.000$ & $100 \pm 0.000$ \\
\hline \multicolumn{3}{|c|}{ Minimum lethal concentration $(\mu \mathrm{g} / \mathrm{mL})^{b}$} \\
\hline $\mathrm{LC}_{50}{ }^{\mathrm{c}}$ & $29.57(25.940-34.766)$ & $29.02(25.836-36.496)$ \\
\hline $\mathrm{LC}_{90}{ }^{\mathrm{d}}$ & $46.21(36.103-55.434)$ & $42.29(38.594-62.060)$ \\
\hline $\mathrm{LC}_{50 \text { (permethrin) }}$ & 1.32 & \\
\hline LC 90 (permethrin) & 1.01 & \\
\hline
\end{tabular}

The larvicidal action of $M$. dandyi was comparable to many other essential oils screened against Ae. albopictus. The minimum lethal concentrations $\left(\mathrm{LC}_{50}\right)$ of Ruta chalepensis, Artemisia verlotiorum and Lavandula dentata essential oils against the vector mosquito of Ae. albopictus, were $93.60,324.00$ and $602.80 \mu \mathrm{L} / \mathrm{L}$ respectively [8]. The essential oils of Erechtites hieraciifolius and E. valerianifolius showed good larvicidal activity against Ae. albopictus with $\mathrm{LC}_{50} 10.5$ and $5.8 \mu \mathrm{g} / \mathrm{mL}$, respectively at $24 \mathrm{~h}$ test period [9]. Eucaluptus nitens exhibited larvicidal action against Ae. albopictus with $\mathrm{LC}_{50}$ of $28.19 \mathrm{ppm}$ [10], while $\mathrm{LC}_{50}$ value of $72.86 \mu \mathrm{g} / \mathrm{mL}$ was obtained for A. macrostemon [11]. Previous study revealed that the essential oil of Severinia monophylla showed potent larvicidal acivity against Ae. albopictus with $\mathrm{LC}_{50}$ value of $36 \mu \mathrm{g} / \mathrm{mL}$ after $48 \mathrm{~h}$ [12]. Eucalyptus globulus and Azadirachta indica were also shown to be effective larvicides with $\mathrm{LC}_{50}$ of $93.3 \mathrm{ppm}$ and $78.52 \mathrm{ppm}$ respectively [13]. The essential oils of Amyris balsamifera, Piper nigrum, Cinnamomum zeylanicum, Anethum graveolens, Jasminum grandiflorum, Juniperus communis and Thymus serpyllum displayed larvicidal activity against Ae. albopictus with $\mathrm{LC}_{50}$ values of 39.8, 62.78, 45.58, 10.52, 49.99, 53.22 and $60.31 \mathrm{ppm}$ respectively [14]. The oil of Toddalia asiatica exhibited toxicity towards Ae. albopictus with $\mathrm{LC}_{50}$ of $69.09 \mu \mathrm{g} / \mathrm{mL}[15]$.

The observed mosquito larvicidal activity of the essential oil may be due to actions of the major compounds or a synergy between the major and some minor constituents. The larvicidal actions of the main compounds of the essential oils have been reported. (E)-Nerolidol, a main constituent of the essential is known for its insecticidal and ovipositor deterrent [16,17]. Essential oil with high contents of $(E)$-nerolidol and $\alpha$ selinene displayed toxicity towards larvae of Ae. albopictus [16]. A mixture of (E)-caryophyllene, $\alpha$-humulene and terpinen-4-ol efficiently deterred oviposition in insects [18]. Cadinene, amongst others displayed the most effective larvicidal activity against Anopheles stephensi, Ae. aegypti and Culex quinquefasciatus [19]. 


\section{Conclusions}

The current study, being the first of its kind, provided information on the medicinal uses and phytochemical compounds in the essential oils of the leaves and fruits of $M$. dandyi. The major compounds were identified as $(E)$-nerolidol, $\alpha$-selinene, $\beta$-caryophylene, $\delta$-cadinene, $\alpha$-humulene and $\alpha$-copaene. In addition, the leaf oil fraction of $M$. dandyi displayed potent mortality and larvicidal activity against Ae. albopictus

\section{Acknowledgments} analysis.

We are grateful to Dr. AbduRauf Oyedapo, LAUTECH, Ogbomoso, for his assistant in statistical

\section{Supporting Information}

Supporting Information accompanies this paper on http://www.acgpubs.org/journal/recordsof-natural-products

\section{ORCID}

Pham H. Ban: 0000-0002-4794-6392

Le D. Linh: 0000-0001-7490-7232

Le T. Huong: 0000-0003-1123-2037

Tran M. Hoi: 0000-0001-6657-1090

Nguyen H. Hung: 0000-0002-5580-2487

Do N. Dai: 0000-0002-7741-9454

Isiaka A. Ogunwande: 0000-0002-5423-887

\section{References}

[1] T.M. Hoi, D.N. Dai, C.T.T. Ha, H.V. Anh and I.A. Ogunwande (2019) Essential oil constituents from the leaves of Anoectochilus setacues, Codonopsis javanica and Aristiochia kwangsiensis from Vietnam, Rec. Nat. Prod. 13, 281-286.

[2] L.D. Dinh, P.H. Ban, D.N. Dai, N.V. Hung, D.B. Thin, V.T. Dung and I.A. Ogunwande (2019) Analysis of essential oils of Phoebe paniculata (Wall. ex Nees) Nees and Phoebe tavoyana (Meissn.) Hook. f. from Vietnam, J. Essent. Oil-Bear. Plant. 22, 231-238.

[3] D.N. Dai, T.D. Thang and I.A. Ogunwande (2016). Essential oil composition of four Magnoliaceae species cultivated in Vietnam, J. Herbs, Spices Med. Pl. 22, 279-287.

[4] K.Y. He, S.Q. Zhang, X.C. Li, Y.S. Fan and X.Y. Jin (2007). Chemical composition and free radical scavenging activity of extracts from three Manglietia species, J. For. Res. 18, 193-198.

[5] National Institute of Science and Technology (2011). Chemistry Web Book. Data from NIST Standard Reference Database 69.

[6] A. Tawatsin, P. Asavadachanukorn, U. Thavara, P. Wongsinkongman, J. Bansidhi, T. Boonruad, P. Chavalittumrong, N. Soonthornchareonnon, N. Komalamisra and M.S. Mulla (2006). Repellency of essential oils extracted from plants in Thailand against four mosquito vectors (Diptera: Culicidae) and oviposition deterrent effects against Aedes aegypti (Diptera: Culicidae), South East Asian J. Trop. Med. 37, 915-931.

[7] J.U. Rehman, A. Ali, N. Tabanca, V. Raman, B. Demirci, K.H.C. Başer and I.A. Khan (2013). Biting deterrent and larvicidal activity of essential oils of Magnolia grandiflora against Aedes aegypti, Planta Med. 79, P-20.

[8] S. Bedini, G. Flamini, R. Ascrizzi, F. Venturi, G. Ferroni, A. Bader, J. Girardi and B. Conti (2018). Essential oils sensory quality and their bioactivity against the mosquito Aedes albopictus, Scient. Rep. 8, 17857. 
[9] N.H. Hung, P. Satyal, H.V. Hieu, N.T.H. Chuong, D.N. Dai, L.T. Huong, T.A. Tai and W.N. Setzer (2019). Mosquito larvicidal activity of the essential oils of Erechtites species growing wild in Vietnam, Insects. 10, 47-57.

[10] A.A. Costa, C.V. Naspi, A. Lucia and H.M. Masuh (2017). Repellent and larvicidal activity of the essential oil from Eucalyptus nitens against Aedes aegypti and Aedes albopictus (Diptera: Culicidae), J. Med. Entomol. 54, 670-676.

[11] X.C. Liu, Q. Liu, L. Zhou and Z.L. Liu (2017). Evaluation of larvicidal activity of the essential oil of Allium macrostemon Bunge and its selected major constituent compounds against Aedes albopictus (Diptera: Culicidae), Parasit. Vectors. 74, 184-189.

[12] P. Satyal, H.V. Hieu, N.T.H. Chuong, N.H. Hung, L.H. Sinh, P.V. The, T.A. Tai, V.T. Hien and W.N. Setzer (2019). Chemical composition, Aedes mosquito larvicidal activity, and repellent activity against Triatoma rubrofasciata of Severinia monophylla leaf essential oil, Parasitol. Res. 118, 733-742.

[13] T. Kaura, A. Mewara, K. Zaman, A. Sharma, S.K. Agrawal, V. Thakur, A. Garg and R. Sehgal (2019). Utilizing larvicidal and pupicidal efficacy of Eucalyptus and neem oil against Aedes mosquito: An approach for mosquito control, Trop. Parasitol. 9, 12-17.

[14] V. Tyagi, R. Yadav and V. Veer (2017). Laboratory evaluation of certain essential oils for their larvicidal activity against Aedes Albopictus, vector of dengue and chikungunya, Glob. J. Zool. 1, 003006.

[15] X.C. Liu, H.W. Dong, L. Zhou, S.S. Du and Z.L. Liu (2013). Essential oil composition and larvicidal activity of Toddalia asiatica roots against the mosquito Aedes albopictus (Diptera: Culicidae), Parasitol. Res. 112, 1197-1203.

[16] W.K. Chan, T.H. Loh, K.G. Chan, L.H. Lee and B.H. Goh (2016). Nerolidol: A sesquiterpene alcohol with multi-faceted pharmacological and biological activities, Molecules. 21, 529-562.

[17] S. Zoubiri and A. Baaliouamer (2014). Potentiality of plants as source of insecticide principles. J. Saudi Chem. Soc. 18, 925-938.

[18] R.C.S. da Silva, P. Milet-Pinheiro, P.C.B. da Silva, A.G. da Silva, M.V. da Silva, D.M. Navarro and N.H. da Silva (2015). (E)-Caryophyllene and $\alpha$-humulene: Aedes aegypti oviposition deterrents elucidated by gas chromatography-electrophysiological assay of Commiphora leptophloeos leaf oil, PLOS ONE. 10, e0144586.

[19] M. Govindarajan, M. Rajeswary and G. Benelli (2016). $\delta$-Cadinene, calarene and $\delta$-4-carene from Kadsura heteroclita essential oil as novel larvicides against malaria, dengue and filariasis mosquitoes, Comb. Chem. High Throughput Screen. 19, 565-571.

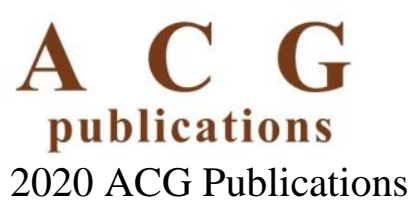

